\title{
Packaging and Microbial Status of Local \& Branded Bakery Products: A Comparative Study on Jessore Region, Bangladesh
}

\author{
Md. Shovon Al-Fuad', Md. Shamimuzzaman², Raju Ahmed', Hd. Razu Ahmmed", \\ Md. Tarek Hasan ${ }^{1}$, Rajib Kanti Roy ${ }^{1, *}$ \\ ${ }^{1}$ Department of Nutrition and Food Technology, Jessore University of Science and Technology, Jessore, Bangladesh \\ ${ }^{2}$ Department of Microbiology, Jessore University of Science and Technology, Jessore, Bangladesh
}

\section{Email address:}

shovon.alfuad@gmail.com (Md. S. Al-Fuad), shamimzaman45@gmail.com (Md. Shamimuzzaman),

rajuahmed9147@gmail.com (R.Ahmed), razu.nft2012@gmail.com (Hd. R. Ahmmed), tareknowshin01@gmail.com (Md. T. Hasan), rajib131kushtia@gmail.com (R. K. Roy)

${ }^{*}$ Corresponding author

\section{To cite this article:}

Md. Shovon Al-Fuad, Md. Shamimuzzaman, Raju Ahmed1, Hd. Razu Ahmmed, Md. Tarek Hasan, Rajib Kanti Roy. Packaging and Microbial Status of Local \& Branded Bakery Products: A Comparative Study on Jessore Region, Bangladesh. Frontiers in Environmental Microbiology. Vol. 4, No. 4, 2018, pp. 103-109. doi: 10.11648/j.fem.20180404.12

Received: July 16, 2018; Accepted: August 9, 2018; Published: September 5, 2018

\begin{abstract}
Background: Most of the people in Bangladesh due to their hectic lifestyles are now increasingly dependent on various bakery products as a source of ready-to-eat foods. Generally, majority of these widely consumed bakery products mainly bread and cakes are supplied by local bakeries. Any chance of unwanted microbial contamination of these popular food products due to any poor manufacturing, handling and packaging practices can lead to major food safety and public health problems. Objectives: This study was aimed to determine and compare the microbiological quality of the locally produced bakery products of Jessore based bakeries with those of branded bakery products produced by renowned food bakeries as well as assessing their relative packaging conditions in respective shops. Method: 120 bakery shops were randomly selected in Jessore region for a questionnaire based data collection. Three types of bakery shops; tea stalls, confectionaries, and variety stores were inspected against their vending extent of branded and local bakery products with associated packaging and visual appearance. Later, 20 samples of cakes $(n=10)$ and breads $(n=10)$ were tested to determine the total fungal count (TFC), total bacterial count (TBC), total Staphylococcus aureus (TSA), total Enterobacteriaceae (TE), and total coliforms count (TC) in $\mathrm{cfu} / \mathrm{g}$. For required statistical data analysis Statistical Package for Social Science (SPSS)-16 software was used. Results: Most of the open (44.6\%) and spoiled (49.4\%) bakery products were found in the Tea stalls. Locally produced bakery products had greater percentage of spoiled bread and cakes compared to their branded counterparts. Breads were more visually spoiled than cakes irrespective of their brands. The number of visually spoiled breads and cakes positively and significantly increased with the number of opened or partially sealed breads and cakes $(\mathrm{r}=0.64, \mathrm{p}<0.01)$. Microbial counts $(\mathrm{cfu} / \mathrm{g})$ in local products were always higher than that of their branded counterparts. Bacterial counts $(\mathrm{cfu} / \mathrm{g})$ in branded products were always lower than local counterparts (Bread, $12.8 \times 10^{7} \pm 3.63 \times 10^{7}$ vs $37.8 \times 10^{7} \pm 19.1 \times 10^{7}, p=0.024$ and Cake, $10.2 \times 10^{7} \pm 3.20 \times 10^{7}$ vs $30.8 \times 10^{7}$ $\left.\pm 21.7 \times 10^{7}, p=0.003\right)$. Coliform count in unpacked sample $\left(4.7 \times 10^{4} \mathrm{cfu} / \mathrm{g}\right)$ was observed much higher than the safety limit for human consumption. Bread and cake produced by local bakeries showed lower standard in packaging and microbial quality. A better manufacturing and packaging initiatives can be introduced to avoid its related food safety concerns in future.
\end{abstract}

Keyword: Local and Branded Bakery Products, Packaging, Microbial Quality, Spoilage 


\section{Introduction}

As life style change of common population occurs at faster rate in developing countries like Bangladesh, people become increasingly dependent on the fast foods, mostly of which consist of various bakery products [1]. Though, there are few major bakery industries which have been able to establish their bakery brands at national levels, they are inadequate. Most of the increasing demand of these baked fast foods is being met by the numerous unauthorized and semiauthorized local producers at smaller scale which are rarely monitored by our current food regulatory organizations. As goes unnoticed this bakery industries eventually push a large number of people at danger of possible food infection and adulteration. Bakery foods have been around from thousands of years and its commercial bread production by yeasts started in Ancient Egypt around 300 B. C [2]. Since, it has become a good source of nutrients like carbohydrates, protein, and fat minerals and vitamins that are essential for maintaining our good health [3]. According to Bakery Equipment Manufacturers and Allieds (BEMA) report global bread consumption saw a jumped $30.1 \%$ from 2005 through 2010 and it is increasing day by day [4]. Bakery industry is one of the major food producing sectors in Bangladesh. These industries have played a momentous role in the economic development of the country. Lately, several nonregistered local bakeries have joined in this emerging market and started manufacturing bakery products in non-hygienic place and with low standard raw materials. Most of them don't have Bangladesh Standards and Testing Institution (BSTI) certification. Commonly, bread and cakes become contaminated at post-baking steps of bakery manufacturing i.e., during cooling, slicing, packaging and storage, from the mold spores present in the atmosphere surrounding loaves. Bacteria like Bacillus, Escherichia and Salmonella, Streptococcus aureus etc may also contaminate bakery items while the products are manually sliced, wrapped and packaged. Similar to the studies [8] in bread molds like Mucor and Rhizopus are found to grow first during bread spoilage. This is followed by some other fungi like Aspergillus, Penicillium and Fusarium sp. [5]. At local small factories, manual wrapping and packaging, poor transport and storage of finished bakery goods may worsen the above microbial contamination compared to that of at large branded bakery producers which are relatively more monitored and regulated by various food safety authorities [6].

As relatively high moisture content encourages the growth and development of mold and bacteria on the bread and cake, any bread and cake if kept open or partially sealed can be infected and deteriorated by airborne fungus, molds and bacteria [7]. Various confectionery, tea stall and variety stores are the main sources of purchase of the bakery products. These bakery vendors don't practice proper storage and vending practices. Often they expose open and unsealed breads and cakes to hot and humid weather that increases the chance of newer microbial contamination and proliferation of previously infected organisms. Food safety became very important for both governments, producers of food products and consumers as well. Like other food products, microbiological hazards have also become a public health safety concern for bakery products [9]. Unhygienic packaging conditions and un-satisfactory storage of bakery products can worsen their microbial quality.

There are 49 bakeries in different brand name and numerous non branded local factories in this south-west region playing an important role of through serving bread and cakes to its huge population in Jessore region [10]. To our knowledge, there was no study which reported the packaging condition and microbial status of local and branded bakery products in Jessore, Bangladesh. Therefore, this study was conducted to analyze microbial count of open and properly sealed bakery products. In addition, the study also focus on the packaging condition of bakery products and to uphold the scenario of local bakery products with health hazard of open bread and cake and also to draw attention of government and other organizations about food safety and packaging. As far very few studies have carried out on comparative analysis of locally produced bakery products and industrially produced bakery products. This study is also intended to have a comparative analysis of presently marketed baked foods with the standards developed by the BSTI.

\section{Materials \& Methods}

A preliminary survey was carried out to gather information on food shops on their branded and local bakery products, specially bread and cake. Questionnaires were directed to fill independently and personally by their choice [11]. Finally, collected data were analysed through SPSS (Statistical packages for social science) statistical program to find out the packaging status and with a view to identifying the average and specific amount of bacteria and fungi, and find out the association of them between local and branded cake and bread.

Collection of sample: A total of $10(5+5)$ branded samples of bread and cake and similarly $10(5+5)$ pieces locally produced bread and cake were collected randomly from different fast food vendors in the various region of jessore region.

Each sample was collected in a sterile sealed polythene bag, appropriately labeled and immediately brought to the microbiology laboratory of Jessore University of Science \& Technology, Bangladesh and stored in the lab before processing.

Sample processing: Each sample $(1.0 \mathrm{~g})$ was homogenized with $0.0 \mathrm{ml}$ of sterile normal saline to prepare standard solution. Then solution was serially diluted $(1: 10)$ to $10^{-5}$ by adding $100 \mu \mathrm{l}$ of stock solution to $900 \mu \mathrm{l}$ normal saline in test tubes. $100 \mu \mathrm{l}$ of diluted sample was inoculated on Nutrient agar (NA), Mannitol Salt Agar (MSA), Membrane Fecal Coliform (MFC), Violet Red Bile Salt Glucose agar (VRBG) 
and Potato Dextrose agar (PDA) media following spread plate method and incubated at $37^{\circ} \mathrm{C}$ for $18-24$ hours except for PDA which was incubated at $28^{\circ} \mathrm{C}$ for $48-72$ hours.

Determination of total bacterial count: Nutrient agar media was used to determine the total bacterial count. NA plates were dried and labeled for appropriate dilutions and we used spread plate method. Plates were inoculated and incubated at $37^{\circ} \mathrm{C}$ for $18-24$ hours. Total number of bacteria in $\mathrm{cfu} / \mathrm{g}$ of sample was calculated and recorded for interpretation of the result.

Determination of Staphylococcus aureus: MSA was used to determine the counts of Staphylococcus aureus in bread and cake samples. The suspected colonies of $S$. aureus showed yellow color for mannitol fermentation and yellow halo for coagulase production around the colony. Suspected colonies were further confirmed by catalase, coagulase tests and Gram staining technique (Cappuccino, 1996). Typical $S$. aureus colonies were counted to calculate cfu per gram of sample.

Determination of total Enterobacteriaceae: Violet red bile salt agar was used for propagation of Enterobacteriaceae. After incubation at $37^{\circ} \mathrm{C}$ for 24 hours characteristic purple and red colonies were counted as members of Enterobacteriaceae. Suspected colonies were counted to determine $\mathrm{cfu} / \mathrm{g}$ (cfu per gram) of sample.

Determination of coliform bacteria: Membrane Fecal Coliform (mFC) media was used to detect the coliform bacteria by using spread plate method. Plates were inoculated and incubated at $37^{\circ} \mathrm{C}$ for 24 hours. All blue colored colonies were enumerated to calculate total coliform as $\mathrm{cfu} / \mathrm{g}$.

Enumeration of yeast and mold: Diluted samples were inoculated on to PDA medium supplemented with clorampheinicol $(40 \mathrm{mg} / \mathrm{L})$ by spread plate method. The plates were incubated at $28^{\circ} \mathrm{C}$ for $48-72$ hours. Visible colonies were counted and recorded as the total yeast and mold in $\mathrm{cfu} / \mathrm{g}$ [12].

\section{Result}

Table 1. Percent distribution of branded and local bakery products among different stores $(N=120)$.

\begin{tabular}{lll}
\hline Types of stores & $\begin{array}{l}\text { Branded bakery } \\
\text { products (\%) }\end{array}$ & $\begin{array}{l}\text { Local bakery } \\
\text { products }(\%)\end{array}$ \\
\hline Tea stall & 11.1 & 36.8 \\
Confectionary & 52.4 & 36.0 \\
Variety store & 36.5 & 27.2 \\
\hline
\end{tabular}

Of the stores which sold bread and cakes, $45.83 \%$ were tea stalls, $34.17 \%$ and $20 \%$ were confectionary and variety stores respectively. Branded bakery products were usually sold by the confectionery and variety stores, whereas tea stalls mostly used to vend local bakery products.

Table 2. Percent distribution of hand-wrapped, unsealed and spoiled bakery products in different stores.

\begin{tabular}{llll}
\hline Types of shop & Hand wrapped bakery product (\%) & Open bakery product (\%) & Visually spoiled bakery product (\%) \\
\hline Tea stall & 36.7 & 44.6 & 49.4 \\
Confectionary & 38.1 & 35.1 & 18.4 \\
Variety store & 25.3 & 20.3 & 32.3 \\
\hline
\end{tabular}

* Bakery products were meant to only bread and cakes

Table 2 reveals that tea stalls had maximum number of unsealed and visually spoiled bakery products; respectively $44.6 \%$ and $49.4 \%$, whereas confectionery stores had the least percent $18.4 \%$ of visually spoiled products. Variety stores had the least percentage $20.3 \%$ of hand wrapped bakery products.

Table 3. Distribution of visually fresh and spoiled bakery products based on the brand of the products.

\begin{tabular}{|c|c|c|c|c|c|c|c|c|}
\hline \multirow{2}{*}{ Variables } & & \multicolumn{4}{|c|}{ Quality of the product } & \multirow{2}{*}{ Total } & \multirow{2}{*}{$X^{2}$} & \multirow{2}{*}{$\mathbf{p}$} \\
\hline & & Fine Bread & Fine Cake & Spoiled Bread & Spoiled Cake & & & \\
\hline \multirow{2}{*}{$\begin{array}{l}\text { Brand type } \\
\text { of products }\end{array}$} & Branded & $4078(62.7 \%)$ & $2125(32.7 \%)$ & $216(3.3 \%)$ & $87(1.3 \%)$ & 6506 & \multirow{2}{*}{296.24} & \multirow{2}{*}{$<0.001$} \\
\hline & Local & $3922(58.0 \%)$ & $1893(28.0 \%)$ & $686(10.1 \%)$ & $265(3.9 \%)$ & 6766 & & \\
\hline
\end{tabular}

The table 3 shows, spoiled bread and cakes were always greater among locally produced products compared to their branded counterparts. Branded products had a longer shelflife than locally produced products. This association was statistically highly significant $(\mathrm{p}<0.001)$. Table- 2 reveals bread were more perishable than cakes. About $10 \%$ of the studied bread was visually spoiled at different stores.

In the study, from figure 1 , it was observed that the number of visually spoiled bread and cakes strongly and significantly increases with the number of opened breads and cakes at different bakery stores $(\mathrm{r}=0.64, \mathrm{p}<0.01)$. Once more, it was found that, following 2.45 visually spoiled products, for increase of each single open bakery product there was a 0.16 times increase of spoiled products at stores. Coefficient of determination $\left(\mathrm{r}^{2}=0.406\right)$ shown on the following figure 1 , indicates that $40.6 \%$ of total variation of spoiled products could be explained by the quantity of open products. 


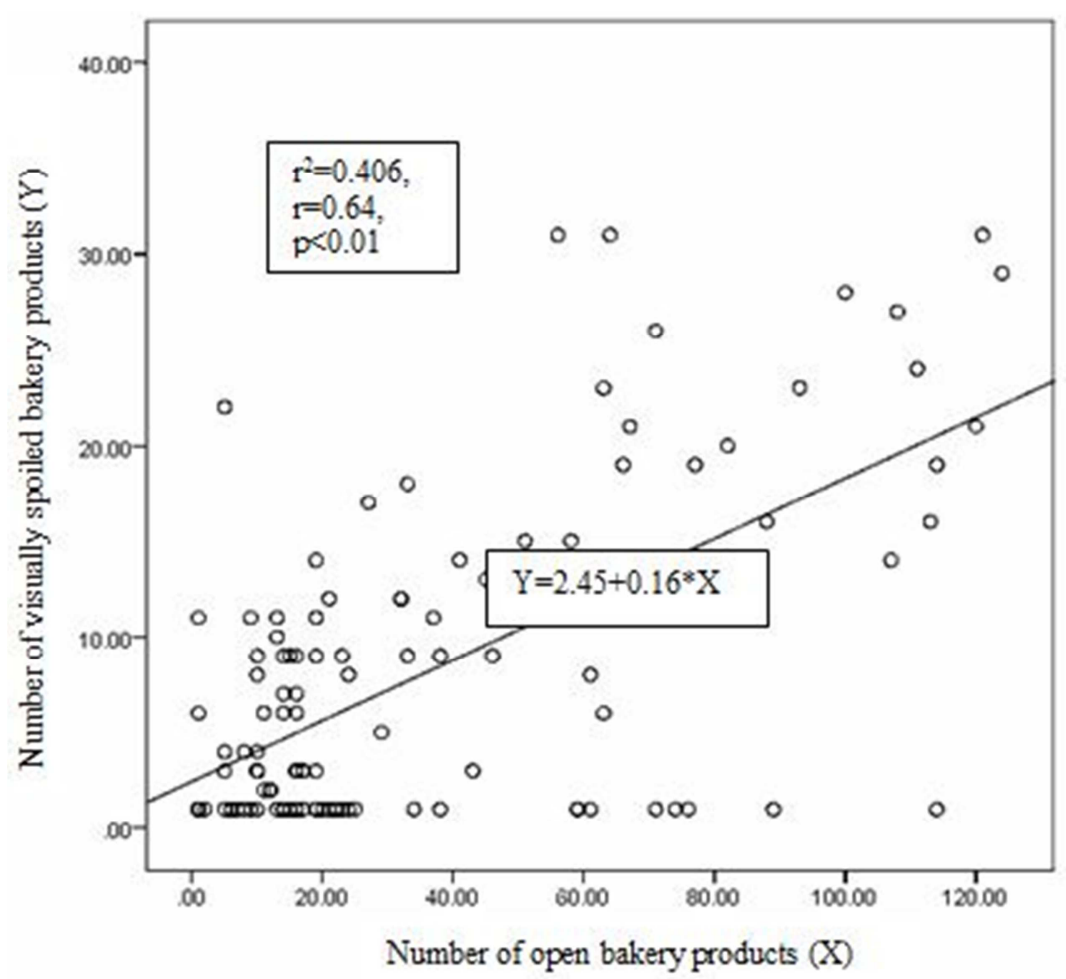

Figure 1. Pearson's linear correlation and regression of the number of visually spoiled bakery products with the number of open bakery products

Table 4. Microbial count (cfu/g) in branded and local bread samples $(N=10)$.

\begin{tabular}{lllllll}
\hline Local Bread & Sample-1 & Sample-2 & Sample-3 & Sample-4 & Sample-5 & Average \\
\hline TBC (cfu/g) & $58 \times 10^{7}$ & $56 \times 10^{7}$ & $37 \times 10^{7}$ & $22 \times 10^{7}$ & $16 \times 10^{7}$ & $37.8 \times 10^{7}$ \\
SA (cfu/g) & $2.63 \times 10^{4}$ & $6.61 \times 10^{4}$ & 0 & $5.35 \times 10^{3}$ & $9.0 \times 10^{2}$ & $1.97 \times 10^{4}$ \\
TE $(\mathrm{cfu} / \mathrm{g})$ & $1.23 \times 10^{4}$ & $9.5 \times 10^{3}$ & $2.3 \times 10^{5}$ & $3.2 \times 10^{4}$ & $3.74 \times 10^{5}$ & $1.32 \times 10^{5}$ \\
TC $(\mathrm{cfu} / \mathrm{g})$ & $1.48 \times 10^{2}$ & 0 & $4.7 \times 10^{4}$ & 0 & $1.2 \times 10^{4}$ & $1.18 \times 10^{4}$ \\
TFC (cfu/g) & $65 \times 10^{7}$ & $79 \times 10^{7}$ & $7 \times 10^{7}$ & $26 \times 10^{7}$ & $21 \times 10^{7}$ & $39.6 \times 10^{7}$ \\
Branded Bread & & & & & & \\
TBC (cfu/g) & $15 \times 10^{7}$ & $14 \times 10^{7}$ & $9 \times 10^{7}$ & $9 \times 10^{7}$ & $17 \times 10^{7}$ & $12.8 \times 10^{7}$ \\
SA (cfu/g) & $6.29 \times 10^{3}$ & 0 & $9.1 \times 10^{2}$ & 0 & $3.7 \times 10^{3}$ & $2.18 \times 10^{3}$ \\
TE (cfu/g) & $9.0 \times 10^{3}$ & $2.33 \times 10^{4}$ & $1.5 \times 10^{4}$ & $1.51 \times 10^{4}$ & $3.42 \times 10^{5}$ & $8.08 \times 10^{4}$ \\
TC (cfu/g) & $1.0 \times 10^{2}$ & $2.7 \times 10^{2}$ & $3.4 \times 10^{3}$ & 0 & $8.2 \times 10^{3}$ & $2.39 \times 10^{3}$ \\
TFC (cfu/g) & $5 \times 10^{7}$ & $2 \times 10^{7}$ & $0.3 \times 10^{7}$ & $1 \times 10^{7}$ & $8 \times 10^{7}$ & $3.26 \times 10^{7}$ \\
\hline
\end{tabular}

$* \mathrm{TBC}=$ Total Bacterial Count; $\mathrm{SA}=$ Staphylococcus Aureus; $\mathrm{TE}=$ Total Enterobacteriaceae; $\mathrm{TC}=$ Total coliforms; $\mathrm{TFC}=$ Total Fungal Count

From the table 4, it was found that overall concentrations of Staphylococcus aureus showed similar pattern having higher concentration in local $\left(1.97 \times 10^{4} \mathrm{cfu} / \mathrm{g}\right)$ than branded $\left(2.18 \times 10^{3} \mathrm{cfu} / \mathrm{g}\right)$ bread samples. Average counts of total
Enterobacteriaceae were $1.32 \times 10^{5} \mathrm{cfu} / \mathrm{g}$ and $8.08 \times 10^{4} \mathrm{cfu} / \mathrm{g}$ in local and branded bread samples, respectively. Mean of total coliform counts in local bread $\left(1.18 \times 10^{4} \mathrm{cfu} / \mathrm{g}\right)$ was higher than that of branded $\left(2.39 \times 10^{3} \mathrm{cfu} / \mathrm{g}\right)$ sample.

Table 5. Microbial load (cfu/g) in sealed and unsealed cake samples $(N=10)$.

\begin{tabular}{llllll}
\hline Local cake & Sample-1 & Sample-2 & Sample-3 & Sample-4 & Sample-5 \\
\hline TBC $(\mathrm{cfu} / \mathrm{g})$ & $46 \times 10^{7}$ & $61 \times 10^{7}$ & $14 \times 10^{7}$ & $11 \times 10^{7}$ & $22 \times 10^{7}$ \\
SA $(\mathrm{cfu} / \mathrm{g})$ & $1.6 \times 10^{4}$ & $2.89 \times 10^{3}$ & $5.72 \times 10^{4}$ & $4.0 \times 10^{3}$ & $7.0 \times 10^{2}$ \\
TE $(\mathrm{cfu} / \mathrm{g})$ & $1.54 \times 10^{4}$ & $6.0 \times 10^{3}$ & $2.6 \times 10^{5}$ & $3.2 \times 10^{4}$ & $3.23 \times 10^{5}$ \\
TC $(\mathrm{cfu} / \mathrm{g})$ & $1.4 \times 10^{4}$ & 0 & $1.2 \times 10^{3}$ & $1.1 \times 10^{3}$ & $5.8 \times 10^{4}$ \\
TFC (cfu/g) & $32 \times 10^{7}$ & $78 \times 10^{7}$ & $8 \times 10^{7}$ & $1.27 \times 10^{5}$ & $1.48 \times 10^{4}$ \\
Branded cake & & & & $12 \times 10^{7}$ & $29.4 \times 10^{7}$ \\
TBC (cfu/g) & $13 \times 10^{7}$ & $13 \times 10^{7}$ & $12 \times 10^{7}$ & $6 \times 10^{7}$ & $7 \times 10^{7}$ \\
SA (cfu/g) & $3.2 \times 10^{3}$ & $1.12 \times 10^{2}$ & $1.4 \times 10^{2}$ & 0 & $2.2 \times 10^{2}$ \\
TE (cfu/g) & $9.25 \times 10^{3}$ & $4.4 \times 10^{3}$ & $2.0 \times 10^{3}$ & $3.7 \times 10^{3}$ & $1.56 \times 10^{4}$ \\
TC (cfu/g) & 0 & $3.14 \times 10^{2}$ & $5.5 \times 10^{2}$ & 0 & $7.34 \times 10^{2}$ \\
TFC (cfu/g) & $1 \times 10^{7}$ & $3 \times 10^{7}$ & $6 \times 10^{7}$ & $6.99 \times 10^{3}$ \\
\hline
\end{tabular}

$* \mathrm{TBC}=$ Total Bacterial Count; $\mathrm{SA}=$ Staphylococcus Aureus; $\mathrm{TE}=$ Total Enterobacteriaceae TC $=$ Total coliforms; $\mathrm{TFC}=\mathrm{Total}$ Fungal Count

*Unsealed/Unwrapped/Unpacked/open=Local 
Mcrobial load in both branded and local cake samples tested in this study is shown in Table 5. The average counts of total Staphylococcus Aureus were $1.61 \times 10^{4} \mathrm{cfu} / \mathrm{g}$ and $7.34 \times 10^{2} \mathrm{cfu} / \mathrm{g}$ in local and branded cake samples, respectively. Averages counts of Enterobacteriaceae was found to be higher in local bread $\left(1.27 \times 10^{5} \mathrm{cfu} / \mathrm{g}\right)$ than branded bread samples $\left(6.99 \times 10^{3} \quad \mathrm{cfu} / \mathrm{g}\right)$. Mean concentrations of total coliform were $1.48 \times 10^{4} \mathrm{cfu} / \mathrm{g}$ and $1.04 \times 10^{3} \mathrm{cfu} / \mathrm{g}$ in local and branded cake samples respectively.

Table 6. Association between bacterial and fungus count in branded and local bread.

\begin{tabular}{llll}
\hline Micro-organism & Type of bread & Mean $( \pm$ SD) & $P$-value \\
\hline \multirow{2}{*}{ Bacteria (cfu/g) } & Branded & $12.8 \times 10^{7}\left( \pm 3.63 \times 10^{7}\right)$ & $0.024^{*}$ \\
& Local & $37.8 \times 10^{7}\left( \pm 19.1 \times 10^{7}\right)$ & $0.001^{*}$ \\
Fungus (cfu/g) & Branded & $3.3 \times 10^{7}\left( \pm 3.20 \times 10^{7}\right)$ & $39.6 \times 10^{7}\left( \pm 30.8 \times 10^{7}\right)$ \\
\hline
\end{tabular}

${ }^{*}$ Statistically significant

Table 6 reveals that Mean $( \pm \mathrm{SD})$ of bacterial count $(\mathrm{cfu} / \mathrm{g})$ was $12.8 \times 10^{7}\left( \pm 3.6 \times 10^{7}\right)$ vs $37.8 \times 10^{7}\left( \pm 19.1 \times 10^{7}\right)$ between branded and local bread which was statistically significant $(p=0.024)$. Fungal count was higher in local bread $\left(39.6 \times 10^{7}\right.$ $\left.\pm 30.8 \times 10^{7} \mathrm{cfu} / \mathrm{g}\right)$ than branded bread $\left(3.3 \times 10^{7} \pm 3.20 \times 10^{7}\right.$ $\mathrm{cfu} / \mathrm{g})(p=0.001)$.

Table 7. Association between bacterial and fungus count in branded and local cake.

\begin{tabular}{llll}
\hline Micro-organism & Type of cake & Mean $( \pm$ SD) & $P$ P-value \\
\hline \multirow{2}{*}{ Bacteria (cfu/g) } & Branded & $10.2 \times 10^{7}\left( \pm 3.42 \times 10^{7}\right)$ & \\
& Local & $30.8 \times 10^{7}\left( \pm 21.7 \times 10^{7}\right)$ & $0.003^{*}$ \\
Fungus (cfu/g) & Branded & $2.84 \times 10^{7}\left( \pm 2.33 \times 10^{7}\right)$ & \\
& Local & $29.4 \times 10^{7}\left( \pm 28.6 \times 10^{7}\right)$ & $0.001^{*}$ \\
\hline
\end{tabular}

* Statistically significant

Table 7 reveals that Mean $( \pm \mathrm{SD})$ of bacterial count $(\mathrm{cfu} / \mathrm{g})$ was $10.2 \times 10^{7}\left( \pm 3.42 \times 10^{7}\right)$ vs $30.8 \times 10^{7} \quad\left( \pm 21.7 \times 10^{7}\right)$ between branded and local cake which was statistically significant ( $p=0.003)$. Fungal count was higher in local bread $\left(29.4 \times 10^{7} \pm 28.6 \times 10^{7} \mathrm{cfu} / \mathrm{g}\right)$ than branded bread $\left(2.84 \times 10^{7} \pm\right.$ $\left.2.33 \times 10^{7} \mathrm{cfu} / \mathrm{g}\right)(p=0.001)$.

\section{Discussion}

Variety of breads and other bakery products have gained popularity among consumers in the last decade and their sales have been increased notably. Based on the questionnaire based field survey it was found that poorly packaged bread and cake products were mostly found in tea stalls than those of confectioneries and variety stores.

Often, bakery products were messily stored in bakery vendors in the study regions. Infrastructure and storage condition of confectionery and variety stores were better than tea-stalls [13]. The local bakery products which either were wrapped individually and then sealed manually by candle lights or were over-packed in large open or partially sealed poly-packs with more than few pieces together -that increases the chance of those local products to come in contact with airborne microbes, insects, dusts, and hot \& humid environment of the vendors outside. This along with the poor post baking handling and storage conditions in the vendors themselves may be one of the major reasons of high microbial count observed in the local bread and cakes.

Further, at local small factories, manual slicing, wrapping and packaging, and poor transport and storage of finished bakery goods poses greater risk of various microbial contaminations like bacteria, mold and spores in them; compared to the branded bakery items produced at large scale branded bakery producers which are relatively more well monitored and regulated by various food safety authorities [14].

Molds like Mucor, Rhizopus, Aspergillus, Penicillium and Fusarium are usually found to bread and cake spoilage. Bacteria like Bacillus, Escherichia and Salmonella, Streptococcus aureus etc may also contaminate and cause ropiness of the products bakery items while the products are manually sliced, wrapped and packaged and distributed [15].

As relatively high moisture content encourages the growth and development of mold and bacteria on the bread and cake, any bread and cake item when kept open or partially sealed can be infected and deteriorated by airborne fungus, molds and bacteria [7].

A proper vending practice like cleanliness status of retailer or storekeeper was found to link to the microbial status of different food products - that is further strongly believed to connect with the educational status of the vendors [16]. Generally, vendors with low education level don't keep adequate knowledge about food spoilage and its consumer health risk. In the current study, it was found that about $78 \%$ retailers of tea stalls had education only up to primary level, whereas $22 \%$ sellers who belong to variety store and confectionaries had studied up to mere secondary level. In our study, most of the badly sealed and visibly spoiled bakery products (about 50 percent) were more found in tea stalls consequently then in variety store and very few in confectionary stores.

This study reveals that average fungal count ( $\mathrm{cfu} / \mathrm{g}$ ) in local bread was around $39 \times 10^{7} \mathrm{cfu} / \mathrm{g}$, which is beyond their safe consumption limits. Similarly, bacterial count both in 
branded and local bread and cake products concernedly found to fall in the unsatisfactory limit of microbiological guidelines for ready-to-eat foods [17]. However, significant difference was found between the enumeration of TBC and TFC of branded and non-branded bread and cake samples $(\mathrm{p}<0.05)$.

To produce enterotoxin, it requires a high dose of Staphylococcus aureus $\left(10^{5}-10^{6} \mathrm{cfu} / \mathrm{g}\right)$ in food [17]. In the present study, average count of $S$. aureus was found to be higher in unpacked $\left(1.61 \times 10^{4} \mathrm{cfu} / \mathrm{g}\right)$ than packed $\left(7.34 \times 10^{2}\right.$ $\mathrm{cfu} / \mathrm{g}$ ) cake samples. Therefore, both of cakes, local and branded showed bacterial loads lower than that required Staphylococcus aureus for effective enterotoxin production.

Average counts of $S$. aureus were $1.97 \times 10^{4}$ and $2.18 \times 10^{3}$ $\mathrm{cfu} / \mathrm{g}$ in unpacked and packed bread samples, respectively. In another study, Daniyan et al. (2011) [18], observed S. aureus count in different stages of bread production which included mixing, milling and baking and after baking they found $2.20 \times 10^{4} \mathrm{cfu} / \mathrm{g}$ Staphylococcus aureus in bread samples.

Coliform group are indicator microorganisms that provide signal about how strictly hygienic standard maintained during the different stages of production. Any presence of coliforms in food sample can suggest that other enteric pathogenic bacteria may present in the samples and these may later increase the greater risk posing to public health [19].

In this study, coliform was found to be present in both cake and bread samples. The highest count of coliforms in packed and unpacked bread samples were $2.39 \times 10^{3} \mathrm{cfu} / \mathrm{g}$ and $1.18 \times 10^{4} \mathrm{cfu} / \mathrm{g}$ respectively. International microbiological standards recommended the safe consumption limit for dry and ready to eat foods are $10^{2}-10^{3} \mathrm{cfu} / \mathrm{g}$ for coliform bacteria [18]. This implies, unpacked breads were unsafe according to the above safety limit in terms of coliform contamination.

Several previous studies done in Pakistan and Australia reported presence of coliform from $10^{2}$ to $10^{5} \mathrm{cfu} / \mathrm{g}$ in cake samples [19]. In accordance with, in the current study, average counts of coliforms were found as $1.04 \times 10^{3}$ and $1.48 \times 10^{4} \mathrm{cfu} / \mathrm{g}$ for packed and unpacked cakes respectively. The greater frequency and average higher load of coliform bacteria in unpacked cakes reminds their poor and inefficient post baking conditions and practices like packaging, handling, and storage [20].

So, in case of the current study, the poor hygiene and wrapping conditions noticed after baking can validate the observed higher microbial contamination of local bread and cake products [21].

Local bakeries depend on manual or hand wrapping for the packaging of bakery products which puts the products at a great risk of microbial contamination from the hands of packaging employees. On the contrary, this chance is minimal for branded bakery products due to its automated sealing and wrapping facilities [17].

\section{Conclusion}

Local unpacked bakery products were inferior to branded and packed ones considering their overall microbial and packaging quality. Pathogenic microbes like coliforms were over the safety limit in locally manufactured bread and cake products. The high prevalence of Staphylococcus $s p$, Enterobacteriaceae $s p$. in the finished foods signals the poor hygiene and handling practices suffered earlier by the products in post baking processes. Comparatively, poor wrapping, packaging and storage status of local bakery products alarmingly affected their microbial wholesomeness. High load of pathogenic microbes and poor packaging condition of the bakery products (Bread and Cake) requires the attention of the Food safety authorities at national level. It is urgent that besides taking measures to prevent the unplanned set up of local bakery factories and implementing the standards for proper manufacturing and marketing bakery products food safety authorities like BSTI (Bangladesh Standard and Testing Institute) should arrange food quality and safety education campaign among the production and packaging employees as well as among vendors.

\section{Declaration of Interest}

The authors report no conflicts of interest. The authors alone are responsible for the content and writing of this article.

\section{Acknowledgements}

Authors are thankful to the Department of Nutrition and Food Technology and Department of Microbiology, Jessore University of Science and Technology, Bangladesh for all their technical help.

\section{References}

[1] Deliens T., P. Clarys, I. D. Bourdeaudhuij, and B. Deforche, "Determinants of eating behaviour in university students: a qualitative study using focus group discussions", BMC Public Health. 2014, vol. 14, pp. 53-57.

[2] Abdullah. N, Nawawi. S, Zainon. N, Bujang. A (2016). Microbiological Quality of Chocolate Cake at Retail Outlet Storage in the Perspective of Halalan-Toyiban; 6(9) 59-63.

[3] S. O. Oluwajoba, O. Malomo, O. A. B. Ogunmoyela, O. E. O. Dudu, and $A$. Odeyemi, "Microbiological and nutritional quality of warankashi enriched bread," Journal of Microbiology, Biotechnology and Food Sciences, vol. 2, no. 1, pp. 42-68, 2012.

[4] Malovany, D. (2011). Doruk's total Bakery Solution. Baking \& Snack International, bakingbusiness.com: 05-12.

[5] Nirmala Ravimannan, Pathmanathan Sevvel, Selvaratnam Saarutharshan. (2016). Study on fungi associated with spoilage of bread. Int. J. Adv. Res. Biol. Sci. 3(4): 165-167.

[6] A. K. Huq O., Md. Uddin J., K. M. Haque F., Roy P., M. Hossain B. (2013). Health, Hygiene Practices and Safety Measures of Selected Baking Factories in Tangail Region, Bangladesh; 10(2): 68-75. 
[7] Ponte, J G and Tsen, C C (1978) Bakery products in Food and Beverage Mycology (ed, L. R. Beuchat); 191-223.

[8] Banwart, G. J. (2004). Basic Food Microbiology. A Westport Publication. Pp. 505-544.

[9] Islam, G. M. R. and Hoque, M. M. (2013). Food safety regulation in Bangladesh, chemical hazard and some perception to overcome the dilemma. International Food Research Journal; 20(1): 47-58.

[10] BBS (2013). Statistical Yearbooks. Bangladesh. Bangladesh Bureau of Statistics, Statistics.

[11] Salami, R. B., "Consumer buying criteria for National and Premium Own-label Food Brands" 2011.

[12] Aydin, A., Paulsen, P., Smulders, J. M. (2009). The physicochemical and microbiological properties of wheat cake in Thrace. Turkish J. Agri. Forestry; 33: 445-454.

[13] Morisaki. M., SUDA. F., "Patrimonialisation of Foods and Agriculture in Japan”. pp-16-20.

[14] Cappuccino, J. G., and Sherman, N. 1996. A laboratory manual in general microbiology. 4th ed. Benjamin Commius publication company, California.
[15] Al-Defiery, M. E. and Merjan, A. F. Mycoflora of mold contamination in wheat flour and storage wheat flour. Mesop. Environ. J, 2015, Vol. 1, No. 2, pp. 18-25.

[16] Abdulkareem. L., Garba. D and Abubakar. A, "A study of cleanliness and sanitary practices of street food vendors in Northern Nigeria", Advances in Food Science and Technology Vol. 2 (5), pp. 209-215, May, 2014.

[17] Gilbert, R. G. (2000). Guidelines for the microbiological quality of some ready-to-eat food samples at the point of sale. Communicable Disease and public health 3: 163-167.

[18] Daniyan, S. Y., and Nwokwu, O. E. (2011). Enumeration of microorganisms associated with the different stages of bread production in Futmin bakery, Nigeria. Int. Res. J. Pharmacy. 2 (7): 88-91.

[19] Afsana, K., Tahmina, S. and Kabir, M. S. (2016). Determination of microbiological quality of packed and unpacked bread. Stamford J. microbiology; 6(1): 24-29.

[20] Oi-Wah, L., and Wong S. K. 2000. Contamination in food from packaging material. J. Chromatogra. A; 882 (1-2): 255270 .

[21] Lakshmi J, "Theory study materialof Bakery and Confectionary Products", 2011. (ICMSF, 1978). 